\title{
Legislation of CSR-Smart Strategy for Sustainable Growth Model in India
}

\author{
Ishita Dutt ${ }^{1 *}$ and Asha Nagendra ${ }^{2}$ \\ 'Symbiosis Centre for Management Studies, Symbiosis International University, Pune-411014, \\ Maharashtra, India; ishita.dutt@scmspune.ac.in \\ ${ }^{2}$ Symbiosis Institute of Management Sciences, Symbiosis International University, Pune-411020, \\ Maharashtra, India; asha.nagendra@sims.edu
}

\begin{abstract}
Objectives and Purpose: The purpose of this paper is to analyze the initiatives covered in Corporate Social Responsibility (CSR) after the passing of the New Companies Act, 2013 and its impact on the growth trends of India. Design/Methodology/Approach: Primary data was collected from 48 top companies in India. This was done by face to face in depth interviews of Sr. Executives, Presidents, Vice Presidents, and Chief Executive Officers of company's CSR Department, Human Resource Department, Public Relations and Corporate communications Department. Statistical Package for Social Sciences (SPSS) was used to carry out the analysis. Binomial tests were used as Statistical Tools to validate the results. Findings: Results indicate more focus on inclusive growth. Corporate houses have started improving the overall quality of life of people in the communities around their premises. Expenditures initiated towards CSR activities are now reported and mentioned in their Annual Reports under separate heads of CSR. The findings are exceptional in nature as this kind of practice was not followed by most of the companies till the passing of the New Companies Act, 2013. The 2\% net profits after tax have shifted from shareholders outlook to stakeholders' outlook. Conclusion/ Improvements: To conclude, ever since the country took initiatives to have it legalized, there has been a paradigm shift in the CSR policies in Indian companies. However, Indian companies need more personnel with specialized qualification of CSR at the top level. Originality/Value: The paper introduces a framework to enable more inclusiveness by providing socially responsible initiatives to the weaker section of the society for improving the overall growth pattern of India. Paper Type: Empirical Research Paper
\end{abstract}

Keywords: Companies Act 2013, Corporate Social Responsibility, Inclusive Growth

\section{Introduction}

CSR is fundamentally a perception whereby companies settle on freely to have a say to improve society and a cleaner surrounding. CSR is represented by the assistance undertaken by companies to society through its company activities and its social venture. This is also to bond the notion of sustainable expansion to the company's attitude. CSR is a steady outline of private firms undertaking additional responsibility than they are obligatory to do under relevant laws and system governing the environment, worker, safety and health and investments in the communities in which they operate.

Over the last few years a growing number of companies universally started promoting their CSR strategies for the reason that the consumers, the community and the investors anticipate them to act sustainable as well as dependable. In most cases, CSR is a consequence of a diversity of social, environmental and economic pressures.

With the increasing Globalization and its adverse side effects, CSR has become the need of the hour. The industries across the world are facing challenges for many years to identify social, economic and environmental issues that are the key drivers of its competitiveness at present as well as in future. If these challenges are to be addressed then the management must understand the integration of social, economic and environmental factors. These are the three parameters to gauge business

\footnotetext{
* Author for correspondence
} 
performance under Triple Bottom Line (TBL). It will also be the source of their competitive advantage and business opportunity. This integration would overlay the technique to all round development, growth and sustainability.

From the socio-economic perspective, CSR is both a value and a strategy to ensuring the sustainability of business. It is a value because it stresses the fact that business and markets are essentially aimed at the wellbeing of society. It is a strategy because it helps to reduce social tensions and facilitate markets.

\section{Global Problems - An Overview}

International competition is a result of Indian economy being a part of global economy. A tremendous pressure is placed by the stakeholder of the corporate sector for accountability and transparency. The economic structure of India has changed drastically over last few decades. But the benefits of growth had not been widely spread to the various sections of the society. Only some part of it reached marginally to low income groups. The repercussion of poverty is multidimensional. The consequences of poverty are deprivation in income, illiteracy, malnutrition, mortality, morbidity, denial of easy access to water and sanitation, vulnerability to economic shocks etc. Income deprivation is linked in many cases to other forms of deprivation

The United Nations Development Programme (UNDP) report on Human Development Index defined human development thus, "It is the process of widening people's choices and the level of well-being they achieve are at the core of the notion of human development." The report further values the social, political and economic freedoms of individuals. To have a higher human development index each individual should be allowed to enjoy one's self respect, human rights gender equality and poverty alleviation.

\section{Progress of Reforms after 1991}

The government of India had decided to privatize a certain percentage of non -performing Public Sector Enterprises (PSEs) after the economic reforms of 1991. This led to two opposing camps. One school of thought believed in the power of markets to distribute only the rewards to the factors of production. This would be a purely capitalist laissez-faire economy without the interference of the state. The other felt that there should be an economy with active role of government in managing the country's economic affairs. It spoke about a welfare state and wealth concentration and distribution as a fair act. The profit rising in exponential rate would lead to unethical practices such as high level of corruption, mismanagement and inefficiency.

Every country tries to raise the standard of living of its countrymen. The consequences and the impact of ever rising population would be generally as follows:

- Decreasing standard of living

- Increasing capital requirements

- Poverty and inequality

- Increasing unemployment

- Food problem

- Environmental degradation

- Problems of Governance

\section{Review of Literature}

CSR has variously been described in the working paper by Thomas and Nowak, as a 'motherhood issue.' Scholarly articles feel the necessity to examine all-inclusive evaluation and amalgamation of research activities in the field of CSR 'using a paradigmatic and methodological lensf (Taneja et al 2011).

One of the first authors who attempted to define CSR was Bowen (1953). According to Bowen "CSR is the policies, the decisions, and the actions that align with the goals and values of society." After his definition, many authors have defined CSR based on their perception of the concept. There have been arguments in favour and against the design of social responsibility. CSR thus means diverse things to diverse people. The diversity of the concept will depend on who is using the term CSR.

Michael, Porter and Mark Kramerf(2002) find that when it comes to philanthropy, executives increasingly see themselves as caught between critics demanding ever higher levels of CSR and investors applying pressure to maximize short term profits. In response, many companies have sought to make their giving more strategic, but what passes for strategic philanthropy is almost not truly strategic, and often isn't particularly effective as philanthropy. Corporations can use their charitable efforts to improve the competitive context -the quality of the business environment in locations where 
they operate. Using philanthropy to enhance competitive context aligns social and economic goals and improves a company's long term business prospects. Addressing context enables to not only give money but also leverage its capabilities and relationships in support of charitable causes that produces social benefits far exceeding those provided by individual donors, foundations, or even governments. Adopting a context focused approach can make a company's philanthropic activities far more effective.

Taking into account several factors that other authors have used in previous studies to define CSR, Fifka (2009) developed a more business-oriented definition of CSR. He defined CSR as the economic and legal obligation as well as voluntary responsibilities of companies to participate in the social development of the communities where they operate while staying in the limit of their available resources and underlying business strategies.

More recently, Russo and Pirrinif(2010) described a whole new perceptive of CSR. According to them, CSR focuses on stakeholder model now, and it requires companies to build relationships that are more complex with their stakeholders. The corporate sector in India has also started engaging in empowering the communities and villages close to the vicinity of their corporate offices and factories. The net profits after tax have shifted from shareholders outlook to stakeholders' outlook.

Jayanta Bhattacharya (2012) challenges the definition of sustainable industry as because the term sustainability has acquired so many overlapping definitions. Bhattacharya highlights the term 'evolved forms' and argues that the industries that are on the path of sustainability can be viewed in more positive terms.

\section{Companies Act, 2013}

Currently, India is the only country leading in the CSR spending. Interest by industries is taking cavernous extraction and has become a new give back concept of Indian stakeholders. This trend pattern is observed in both developed and developing economies. (Sarkar and Sarkar, 2015).

The Companies Act 1956 has gone through amendment after the passage of the Companies Bill 2013. The Companies Act, 2013 passed by the parliament has received the assent of the President of India on $29^{\text {th }}$ August, 2013. With the immense changes, Sec135, of New Companies Act, 2013 stipulates that: "Every company having net worth of rupees five hundred crores or more, or turnover of rupees one thousand crores or more or a net profit of rupees five crores or more during any financial year shall constitute a CSR Committee of the Board consisting of three or more directors, out of which at least one director shall be an independent director .

The Schedule VII of New Companies Act, 2013 in India deals with such issues. Now, it has been made mandatory that the CSR activities undertaken as a part of $2 \%$ net profit of the average of the preceding three years have to flow in this direction which may lead to higher GDP of the country with all the women employed equally and enjoying equal rights. This is expected to lead to higher HDI in our country. The different parameters needed to be synergized are as follows:

- Miracles of common action

- Enhancing social accountability

- Corporate performance should show relevance to social reality

- Giving legislative sanction to common action on the part of corporate

- Involvement ensures performance

The purpose of this paper is to analyze the initiatives covered in CSR after the passing of the New Companies Act, 2013.

\section{Making CSR Really Matter}

Venkatesan (2014) in his article on 'Making CSR Really Matter' on the compliance of mandatory CSR states that it is estimated 16000 companies will finally have to start discharging their CSR as per the Companies Act, 2013. If companies actually comply with the requirement of spending $2 \%$ of their profits on CSR, an estimated Rs. 20.000 crores or substantial expertise will flow to the social sector. The most important is to graduate from cheque book philanthropy to impact investing. This is a big deal and needs to be approached with the rigor of a venture capitalist. Mutual expectations and impact metrics must be documented in a simple but stringent MOU.

\section{Cos' CSR Estimate Cut by Ministry}

Arora 12 (2014) found that "the corporate affairs ministry has cut by half its internal estimate of CSR spending in 
the first year in part because companies are not very enthusiastic to the idea. The ministry now expects the eligible companies to spend about Rs 5,000 crores; its initial projection was more than Rs. 10,000 crores. It has cut the estimate also after finding discrepancies in the data it relied upon. Under new rules, the companies coming under the purview of CSR Act need to spend at least $2 \%$ of the average net profit of the preceding three years on CSR activities. The ministry had estimated that the companies which come under CSR ambit need to spend the funds on projects ranging from rural development and education to art and culture.

\section{Good Growth}

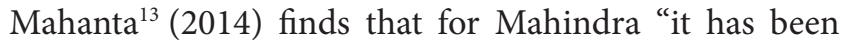
a three step journey that started with the focusing of scattered philanthropic activities of the group. Then the approach shifted to 'strategic philanthropy' a concept floated by Porter that propounds intelligent giving. Now the Mahindra Group has upped the bar a notch by migrating to the 'shared values' concept wherein business and CSR strategies are intermeshed. It was to be a much deeper call to action that would be a spring board for innovation, an execution philosophy and a mantra to build competitive and future ready business models.

Tare (2014) feels that ethics is that bedrock from which the spring of doing well to society sprouts. A business cannot survive and prosper if society fails. Both share an umbilical cord.CSR aims at creating shared value which is based on the belief that corporate success and societal good are interdependent. A business needs a healthy, educated, motivated work force, sustainable resources and enabling regulatory environment to compete effectively. Including CSR as a part of new Companies Act, 2013, the Indian government has commenced a serious, structured and project-driven approach which can bring an impactful shift from one time philanthropic and charitable acts to long term sustainable ventures of social and economic well-being. In passing this law, the government has paved the way for corporate not only to bring their resources but also capacities and skills that enable social change in ways that are beyond the capacities of both government and the civil societies."

In the financial year 2014-15, which is just after passing the New Companies Act, 2013, there has been a rise of $27 \%$ in India's total CSR reporting, as per the KPMG survey. The survey was conducted by KPMG for a maximum of 45 countries across the globe. Passing of the act in India confirms the companies for having project based CSR penetrations within the rural and urban configuration. This will require more elastic resource allocation, distribution and management. The survey by Mukherjeef (2016) shows that Maharashtra being a highly industrialized state has 205 projects in pipeline emerged as one such state where nearly $50 \%$ of the companies are implementing CSR initiatives. It is followed by Karnataka, West Bengal and Tamil Nadu.

\section{Methodology}

The population for the study consisted of all the top 300 listed companies and MNCs operating in India. In case of primary data through questionnaire, all types of companies were taken into consideration. The latest Annual Reports of the top companies with highest turnover reported by Forbes India were also taken into consideration for study. The research is based on case studies, of top listed companies and Multinational Corporation (MNCs) working in India. Both Quantitative and Qualitative analysis has been taken into consideration. SPSS was used to carry out the analysis. Binomial tests were used as Statistical Tools to validate the results.

For the empirical research, the questionnaire was sent to respondents of the topmost 100 companies. These were selected as per 2013 grade of Forbes India in collaboration with India CSR. These rankings are based on prime revenue generating brands which have a capability of doing enormous amount of CSR. The respondents were the top executives holding the posts of CEO, Director, General Manager, President, Sr. Vice President, H.R. Managers, PROs of various companies etc. of their respective companies. Four types of questionnaires were used: through telephonic interview, on line surveys, through email and also through personal interviews.

Wherever, the appointment of the stalwarts of the company had been difficult, the researcher approached the National Stock Exchange (NSE) and Bombay Stock Exchange (BSE) for the provision of the Annual Reports. The primary data collection method was used in the form of questionnaire. Companies located in Pune, Mumbai, New Delhi, Kolkata, Gurgaon, Lucknow, Aurangabad, Noida, Akurdi, Ranjangaon, Chakan, Secunderabad, Dehradun and Jamnagar were approached.

From a total of 69 responses, list wise deletion of missing responses resulted on a final effective and valid 
sample size of 48 . The in-depth interview was conducted to realize the impact of the different aspects of CSR on different categories of industries and also the different sectors. The sectors included are pharmaceutical, insurance, financial, beverages, electro steel castings, energy, chemicals and fertilizers, paper and pulp, information and technology, automobile, housing and construction, road infrastructure, forging, consumer goods, auto dynamics, clothing and garments, electrical, shipping, oil, steam engineering, banks and moulders. All these companies have done CSR in some form or the other. Data from 48 companies was finally used for study, analysis and conclusion.

\section{Results}

The respondents consisted of Managing Director/CEO/ President being 10.42\%; Vice President/Corporate Head of CSR and Sustainability department with $31.25 \%$; General Manager/Head (HR and Admin) being 20.83\%, Vice President Commercial being 6.25\%, Head Operations and Corporate Affairs being $10.42 \%$ and people from other miscellaneous departments being $20.83 \%$. This shows the reliability of data is very high as they are the stalwarts of the company and they would never like to jeopardise their position by giving wrong information of their own organisation. (Refer Table1 and Figure 1)

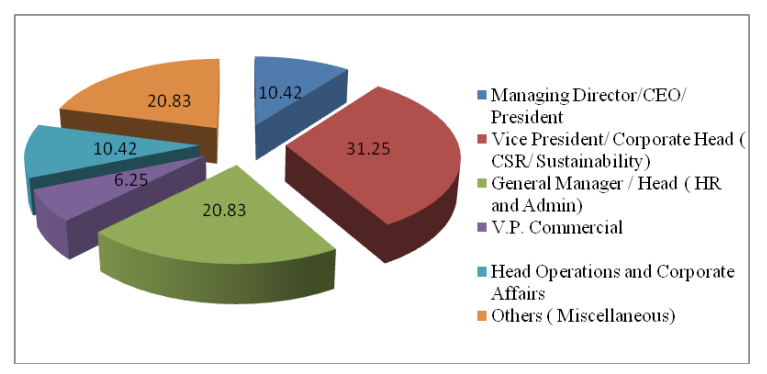

Figure 1. Designation of the respondents.

Table 1. Designation of the respondents

\begin{tabular}{|c|c|c|c|}
\hline S. No. & Designation & Frequency & Percentage \\
\hline $\mathrm{a}$ & Managing Director/CEO/ & 5 & 10.42 \\
\hline & President & & \\
\hline b & Vice President/ Corporate & 15 & 31.25 \\
\hline & Head (CSR/ Sustainability) & & \\
\hline c & $\begin{array}{l}\text { General Manager / Head } \\
\text { ( HR and Admin) }\end{array}$ & 10 & 20.83 \\
\hline d & V.P. Commercial & 3 & 6.25 \\
\hline $\mathrm{e}$ & Head Operations and & 5 & 10.42 \\
\hline & Corporate Affairs & & \\
\hline f & Others ( Miscellaneous) & 10 & 20.83 \\
\hline g & Total & 48 & 100.00 \\
\hline
\end{tabular}

It is not surprising to see that the ratio between male and female respondents was $83.33 \%$ to $16.67 \%$ which indicates that more male employees are in the senior hierarchy than female employees in the organizations in India performing the CSR initiatives. (Refer Table 2 and Figure 2). More women employees are needed in the organizations to carry out CSR initiatives. This is required to minimise the gender related issues which are the most debatable and sensitive issues in India. The women tend to understand the needs and problems faced by the other women and help them by guiding them to protect themselves from the evil impacts of the societal norms. Women are more receptive and sensitive to issues relating to health, nutrition, children etc. Section 149 of the New Companies Act 2013 throws light on women reservation in the Companies Act. However, nothing is mentioned about women dealing with CSR activities in Section 135.

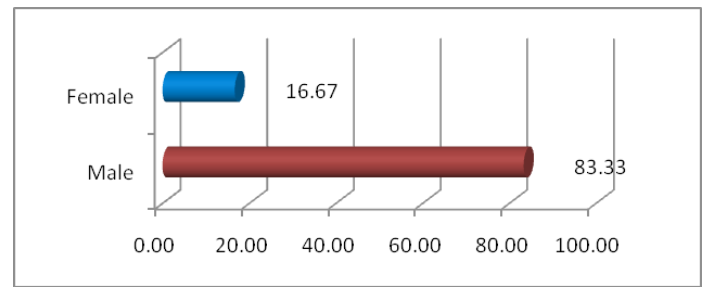

Figure 2. Gender of the people interviewed.

Table 2. Gender of the people interviewed

\begin{tabular}{llcc}
\hline S No & Gender & Frequency & Percentage \\
\hline $\mathrm{a}$ & Male & 40 & 83.33 \\
$\mathrm{~b}$ & Female & 8 & 16.67 \\
\hline & Total & $\mathbf{4 8}$ & $\mathbf{1 0 0}$ \\
\hline
\end{tabular}

$87.5 \%$ of organizations follow specialized CSR initiative whereas $12.5 \%$ follow general philanthropic initiatives. Issues covered under CSR for specialised initiatives were immense and different for different companies. There were overlapping CSR related issues by each company. The research shows that there is a dearth of specialised qualified personnel in the social welfare stream in each organisation. (Refer Table 3 and Figure 3)

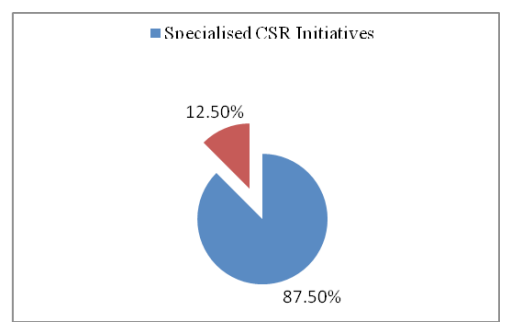

Figure 3. Companies with specialized and general CSR initiative. 
Table 3. Companies with specialized and general CSR initiative

\begin{tabular}{llcc}
\hline S. No & CSR Initiatives & Frequency & Percentage \\
\hline $\mathrm{a}$ & Specialized CSR Initiatives & 42 & 87.5 \\
$\mathrm{~b}$ & General Philanthropic & 6 & 12.5 \\
& Initiatives & & \\
\hline & Total & $\mathbf{4 8}$ & $\mathbf{1 0 0}$ \\
\hline
\end{tabular}

It was found that $77.08 \%$ of the organizations follow regular running events whereas $22.92 \%$ organisations follow onetime events. Amongst the beneficiaries of CSR initiatives, $7.94 \%$ were the respective company's own employees, $28.57 \%$ had assortment of beneficiaries, $1.58 \%$ were the tribal people in any part of the country, $38.10 \%$ were the poor people living in rural areas, $7.94 \%$ were population from the adjoining areas and $15.87 \%$ were from the urban slums. It is seen that the maximum percentage of benefits are allotted for the poor people living in rural areas, the adjoining areas and the population from the urban slums. This states that our country is moving towards more inclusive growth with regularly running events by different companies.

The number of activities taken for consideration for analysis is as follows:

- Health

- Literacy

- Poverty Eradication and Hunger

- Environment Management

- Water Management

- Financial Inclusion

- Rural Development and Model Village

- Women Empowerment

- Programmed for Girl Child

- Sports Initiative

- National Heritage

- Measures for Armed Forces Veteran

- Skill Development Leading to Employment

- Global Compact/ Human Rights

- Occupational Safety and Zero Fatality

- Facilities for Tribal Community

- Initiatives for Physically and Mentally Challenged

- Solar Power PV Installation

Figure 4 reveals that amongst the companies under study, $16 \%$ of them give their topmost priority to healthcare initiatives; $13 \%$ to environment management, ecological balance and carbon foot printing: $12 \%$ give their topmost priority to literacy; $10 \%$ give it to skill development leading to employment; $10 \%$ to occupational safety and zero fatality; $8 \%$ towards water management; $6 \%$ each towards rural development and model village and towards women empowerment: $5 \%$ for poverty eradication and hunger; $4 \%$ each towards financial inclusion, programme for girl child and for the sports initiative; $2 \%$ towards national and cultural heritage; However, $0 \%$ was towards measures for the armed forces veterans, global compact and human rights, facilities for tribal community, for the physically and mentally challenged and also for solar power installation. (Refer Figure 4)

\section{Topmost Priority}

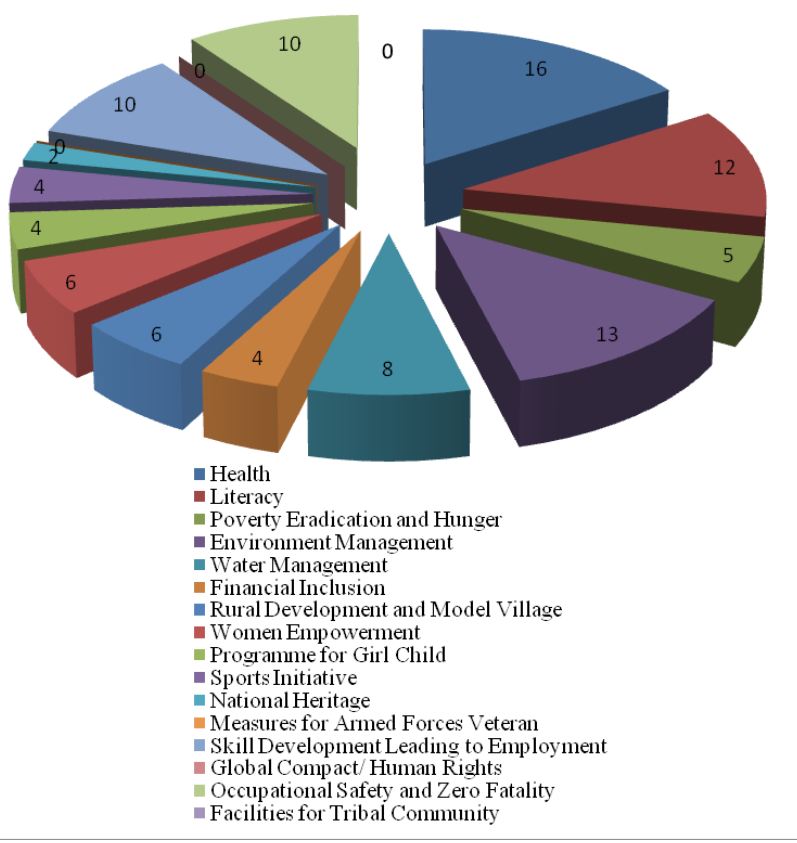

Figure 4. Topmost priority of CSR initiatives.

The study shows that $45.83 \%$ of the projects were modified and redrafted totally followed by $37.5 \%$ modification partially. It is seen that $16.67 \%$ projects have not undergone any modification or redrafting after the launch. This shows that earlier, the companies taking up CSR initiatives exclusively for their own employees had to completely modify the draft after passing of the New Companies Act, 2013 with more inclusion in the CSR initiatives. The data under study show that only $8.33 \%$ of the organizations have reached their CSR activities into different states, while $16.67 \%$ to different districts, $33.33 \%$ 
to different villages and most of them have restricted their CSR activities in the town itself with the percentage being $41.67 \%$. Hence, the coverage and scope have also improved.

It was found that $56.25 \%$ of the companies exclusively allot funds for CSR activities while $43.75 \%$ of the organizations do not exclusively allot the funds for the same and show it in their miscellaneous expenditure. There is no significant association between the size of the firm and the allocation of the funds for CSR. However, to comply with the New Companies Act 2013, it will be mandatory for the companies to allocate funds especially for CSR activities.

$41.67 \%$ respondents opined that budget for CSR rose substantially since the last three years, for $12.5 \%$ respondents, the budget had risen mildly and for $37.5 \%$ respondents it remained constant. For $8.33 \%$ the question did not arise for the change in budget because they are at their infancy stage as far as CSR is concerned as they have started taking CSR initiatives after the passing of New Companies Bill.

The motivation of some of the organizations to come up with the CSR policies is for the welfare of the society. Even the respondents feel that some sections of the society do not receive much support and are less privileged and therefore they need support of the corporate sector. Some respondents opine that the willingness should come from within. They say that CSR activities should not be made obligatory. Some other companies' global approach to citizenship is founded on the belief that business has a crucial role to play in helping solve the world's most complex problems. Some other respondents feel that the motivation of the organizations to come up with the CSR is because of the demand from the society itself and also governmental policies. The first step in CSR implementation is to develop the CSR policy. It is also mandated by the government. Many organizations got motivated to come up with such policies by helping those who really want to learn and grow.

\section{Verification of Hypothesis}

In the research, two hypotheses were framed as follows: Hypothesis 1:

Null Hypothesis $\mathrm{H}_{0}$ : CSR is not an effective catalyst for bringing about positive community change.

Alternate Hypothesis $\mathrm{H}_{1}$ : CSR is an effective catalyst for bringing about positive community change

Hypothesis 2:

Null Hypothesis $\mathrm{H}_{0:}$ CSR mandate of $2 \%$ net profit of the New Companies Act, 2013 is not the real force behind CSR initiatives taken up by the companies.

Alternate Hypothesis $\mathrm{H}_{1}$ : CSR mandate of $2 \%$ net profit of the New Companies Act, 2013 is the real force behind CSR initiatives taken up by the companies.

\section{Hypothesis Testing}

Hypothesis 1: CSR is an effective catalyst for bringing about positive community change.

Statistical Tests: Binomial Test

Variable for Measurement: Respondents were asked to comment on, "Whether CSR is an effective catalyst for bringing about positive community change" using a 3 -point scale ( $1=$ Yes, $2=$ No, $3=$ Can't Say)

Later then 3-point scales were converted into 2-point scale using cut point option as " 2 " for the sake of convenience of binomial test. Hence, the newly created categories are $\leq 2$ : Yes, $>2$ : No.

\section{Test Proportion:}

Test Proportion was taken as 0.75 . Since more than $75 \%$ of favourable responses to a particular category suggest greater approval for this category hence $\mathrm{P}=0.75$

$\mathrm{H}_{0}$ : Proportion of responses indicating "CSR is not an effective catalyst for bringing about positive community change." is equal to or less than $75 \%(\mathrm{P} \leq 0.75)$

$\mathrm{H}_{1}$ : Proportion of responses indicating "CSR is an effective catalyst for bringing about positive community change." is more than $75 \%(\mathrm{P}>0.75)$

Level of Significance $\alpha=0.75$

\{Refer Table 4\}

Table 4. Binomial test

\begin{tabular}{|l|l|c|c|c|c|c|}
\hline \multicolumn{2}{|l|}{ Binomial Test } \\
\hline \multicolumn{2}{|c|}{ Category } & $\mathrm{N}$ & Observed Prop. & Test Prop. & Exact Sig. (1-tailed) \\
\hline \multirow{2}{*}{\begin{tabular}{l} 
CSR is an effective catalyst \\
for bringing about positive \\
\multirow{2}{*}{\begin{tabular}{l} 
community change \\
\cline { 2 - 8 }
\end{tabular}}
\end{tabular}} & Yes & $<=1$ & 42 & .88 & .75 & .027 \\
\cline { 2 - 8 } & To and Can't say & $>1$ & 6 & .13 & & \\
\hline
\end{tabular}




\section{Interpretation of Hypothesis 1:}

Observed Proportion $=0.88$, Test Proportion $=0.75, \mathrm{P}$ value $=0.027$

Since the $\mathrm{P}$ value $(0.000)$ is less than the level of significance (0.05), the null hypothesis is rejected. Hence, the proportion of response indicating "CSR is an effective catalyst for bringing about positive community change." is more than $75 \%$.

Hence the hypothesis "CSR is an effective catalyst for bringing about positive community change" is proved.

This also proves that the $2 \%$ of net profit after tax for the CSR purpose has shifted from shareholders outlook to stakeholders' outlook. The purpose is being solved by the corporate sector getting engaged in empowering the communities and villages close to the vicinity of the corporate sector.

Hypothesis 2: CSR mandate of $2 \%$ net profit of the New Companies Act, 2013 is the real force behind CSR initiatives taken up by the companies.

\section{Statistical Test: Sign Binomial Test}

The company stalwarts were asked to comment on "Is the motivation towards the CSR policies because of the $2 \%$ Net Profit to be spent for CSR initiatives made mandatory after the passage of the Lok Sabha bill in the parliament?" using a two point scale $(1=$ Yes, $2=\mathrm{No})$

\section{Test Proportion:}

Test proportion was taken as 0.5 . Since more than $50 \%$ of favourable responses to a particular category suggest greater approval for this category hence, $\mathrm{P}=0.5$

$\mathrm{H}_{0}$ : Proportion of response indicating, "CSR mandate of $2 \%$ net profit of the New Companies Act, 2013 being not the real force behind CSR initiatives taken up by the companies." Is equal to

$50 \%$. $(\mathrm{P}=0.5)$

$\mathrm{H}_{1}$ : Proportion of response indicating, "CSR mandate of $2 \%$ net profit of the New Companies Act, 2013 being the real force behind CSR initiatives taken up by the companies." Is not equal to $50 \%$. $(\mathrm{P} \neq 0.5)$

\{Refer Table 5\}
ObservedProportion $($ Yes $)=0.23$; Test Proportion $=0.5$; $P$ value $=0.000$

Interpretation of Hypothesis 2: Since P value (0.000) is less than the level of significance, the null hypothesis is rejected and hence it is concluded that the proportion of responses indicating, "CSR mandate of $2 \%$ net profit of the New Companies Act, 2013 is the real force behind CSR initiatives taken up by the companies" is less than $50 \%$ hence the hypothesis CSR mandate of $2 \%$ net profit of the New Companies Act, 2013 is the real force behind CSR initiatives taken up by the companies" is disproved.

Therefore, all the hypotheses have been tested and the results proved/ disproved have been duly marked and accredited.

\section{Conclusion and Future Plans for CSR in India}

Although, CSR has gained extraordinary momentum in the globe, Indian citizens feel good as India is the only country of primary significance in CSR spending and is also completely legalised. Legalisation guidelines lead to great potential towards inclusive growth.

The companies and the government in India have realised the fact that if India has to reduce the struggle of pollution, population explosion, degraded natural resources, unequal distribution of resources, racism, lack of health, food, shelter, hunger, disease, illiteracy etc then corporate sector must join hands with the government. The top organisations in India have started with separate CSR wings as a strategic tool for sustainable growth. The study shows that more focus is needed under CSR for the tribal people in different parts of the country. They are the neglected lot of the population. Schedule VII of the New Companies Act 2013 has no special mention for the tribal people. The companies should be encouraged to uplift these tribal people. Moreover, as per the New Companies Act 2013, the welfare measures taken up for the company's own employees will not be considered as a CSR activity.

Table 5. Sign Binomial test

\begin{tabular}{|l|l|l|l|c|c|c|}
\hline \multicolumn{2}{|l|}{ Binomial Test } & Category & N & Observed Prop. & Test Prop. & Exact Sig. (2-tailed) \\
\hline \multirow{2}{*}{$\begin{array}{l}\text { CSR mandate of 2\% net profit of } \\
\text { the new company's act of 2013 is } \begin{array}{l}\text { the real force behind CSR initiatives } \\
\text { the } \\
\text { taken up by the companies }\end{array}\end{array}$} & Group 1 & Yes & 11 & .23 & .50 & .000 \\
\cline { 2 - 8 } & Group 2 & No & 37 & .77 & & \\
\hline
\end{tabular}


As Joshilf (2016) finds that the new push by the corporate affairs ministry goes against a government proposal to make $30 \%$ of the CSR spends on projects like Swacch Bharat. The government is expecting a fund of approximately Rs 2 lakh crore over the next three years by India Inc. The idea behind such a push is that the prime ministers mission of Swacch Bharat does not lag behind the fascinating projects like Digital India or Start up India. In Maharashtra, government has floated the proposal of 'Maha Plans CSR Drive' with top Industrialists in August, 2016 to transform 10,000 villages over next three years. 1 Government received wholehearted retort from the industrialists. Some industrialists in the board of governing body act as an assurance booster. Most of the companies are practicing CSR which is bringing positive results to the Indian economy. However, the approach by different countries are scattered and moreover of overlapping ideas. The top governmental officials must plan for more harmonized approach with deadlines and goals in place to achieve more sustained Inclusive Growth.

Although, many programmes are taken on the long term basis, yet the extent of cooperation and involvement on the part of beneficiaries are lacking. They need a lot of motivation by the organizations to carry out a project which needs a lot of patience, time and energy. The beneficiaries have lots of doubts in their minds about these corporate and they show a very aggressive attitude towards them. Moreover, the sarpanch is sometimes the only person who communicates with the organizations on CSR activities. The study finds that most of the beneficiaries are identified by the qualified staff within the organization. It was noted by the researchers that these qualified staff are self motivated people and act as social entrepreneur within the organization. They can be named as intrapreneur and these intrapreneurs can take CSR activities to a higher platform. Company policies are the main basis behind targeting the towns, villages, districts and states for their CSR initiatives. Most of the feedback from the beneficiaries is taken randomly. The study reveals that in $33.33 \%$ cases the feedback from the beneficiaries were taken yearly and in $25 \%$ cases, it was taken half yearly. $12.5 \%$ reveal that the feedback is never taken as sometimes the rural beneficiaries are very reluctant to give any positive feedback.

The data reveals that many firms did not go beyond $2 \%$ of Profit after Tax allocated for CSR activities before the passage of the New Companies Act, 2013. The main problems of making CSR projects a success are the problem at the implementation level, non availability of trained personnel and non cooperation at the part of beneficiaries. The study exposes the fact that in most of the companies, CSR committee are appointed by the Board of Directors of their respective organizations. In maximum cases there is no specific time frame for the continuation of CSR programmes.

It is a commitment of the company and its members to give back to the society to bring positive changes in the lives of the less privileged people and to become a sustainable business.CSR and Sustainability projects are undertaken towards improving the quality of lives of the underprivileged sections of the society and other stakeholders primarily around its factories and to bring perceptible change in socio economic life of the local community and society at large. But the commitments are far from reality.

Nevertheless, the constraints faced by the organizations are also enormous. There are critical legal hassles \& still discussion is going on with ministry of Corporate Affairs with no satisfactory results. Most of the beneficiaries do not know the advantages they are entitled for.

There is lack of support from government agencies in certain areas; lack of credible Civil Society organization in different regions. Problem of locating reliable NGOs for implementation on a large scale makes the CSR activities all the more difficult.

The respondents feel that although there is too much documentation yet no idea about which department to consult for a specific CSR project. Budget allocation and right initiative have also been a major constraint. Too many departments are involved in the CSR initiation and Managers fail to come towards a proper consensus on implementation. Identifying the needs of the people and locating right implementation partner is another area of concern. Ownership of facilities for proper operation \& maintenance by the beneficiaries \& selecting credible implementing agencies had been a problem.

Local panchayats or schools are more interested in money than the upliftment in kind. Political interference also impedes CSR initiatives and delay in utilization of resources. Majority of the companies face the constraint of cost while implementing of the CSR initiatives.

Lack of political will, faulty attitudes, and unrealistic expectations from the corporate sector cause a major hindrance. The problem is also faced in Managerial traction/ time, focus and sustainability and followthroughs. 
Awareness - amongst the company's employees to help the management identify the associated benefits of CSR and explain the positive impact on the society in general and Company in particular would bring about more success in the operation of CSR. It is important to have a dedicated team, dedicated resources and follow-through with the end-user for completion. Gain mileage out of it - so integration of Marketing, Sales, Finance and HR efforts for this is a necessary condition to be successful. Indian companies need more personnel with specialized qualification of CSR at the top level.

\section{Recommendations}

While carrying out the research and its survey, various issues and challenges were observed. These issues, challenges and opportunities point out the future of CSR in the country. The recommendations will lead to take necessary steps towards organizations based on CSR practices.

It is necessary to foster economic opportunities to millions of people through greater involvement. Connection amongst the companies are lacking to a great extent. CEOs of the companies should meet once a year and discuss the specific CSR related issues. The government should make such kind of forum and let the private sector take the initiative to join hands with the government to create such forum. In this way, the same CSR activity will reach more number of villages.

In the era of globalization, Indian CSR activities need to get connected with the global social organizations like World Health Organization (WHO), Millennium Development Goals (MDGs) and World Business Council for Sustainable Development (WBCSD) objectives aligning CSR. The checking becomes extremely important with respect to quantity of WBCSD goals achieved through CSR by the corporate houses. The issues are required to be addressed immediately.

The social expenditures of each listed company are needed to be segregated. Total transparency of expenditure is the need of the hour. Suggestions should be invited from time to time from the NGOs and the general public. The beneficiaries should be involved in some of the meetings to check if they really have a visible impact on the community and the society through the CSR projects undertaken.

Each company should aim at publishing their CSR activities in the Global Reporting Initiatives (GRI) report of Amsterdam. It is important to know that where do we stand and where should we set our standards? How do we address the human rights as per the United Nations Global Compact (UNGC) norms? Critical judgment by the evaluator is needed for effective program.

\section{Hard Reality}

The big question remains if CSR performance will fill the gap between the social realities and the corporate performance in the coming years? Will the CSR activities lead to better social governance, better quality of social life coupled with better corporate performance and foster more inclusive growth?

The unique conceptual assessment made by the researchers on the whole will facilitate and enhance further empirical research related to CSR. Introduction of Section 135 and Schedule VII of New Companies Act, 2013 has vitally altered the dynamics of CSR.

\section{Acknowledgement}

I would like to express my sincere gratitude to Dr. S. Dastane for his personal guidance. I gratefully acknowledge Dr. N. Mahankale, Dr. G. John, Prof. N. Khandelwal for their support. My special thanks to Mr. S.P. Ghosh and Mr. G. Bhattacharya for connecting me to the respondents for the research work. I am forever indebted to my husband Mr. J.Dutt, Sister Ms. O. Ghosh and children Shreya and Shoumedhik. My sincere thanks to my mother, father-in law, uncle and late father for their blessings. My truthful thanks to Almighty God for giving me strength to carry out the research work.

\section{References}

1. Fernando AC. Ethical issues in human resource management, Business Ethics: An Indian Perspective, 2/e Dorling Kindersley (India) Pvt. Ltd., Pearson, New Delhi; 2013. p. 437.

2. Taneja SS, Taneja PK, Gupta RK. Researches in CSR: a review of shifting focus, paradigms, and methodologies. Journal of Business Ethics. 2011; 101(3):343-64.

3. Bowen HR, Johnson FE. Social responsibility of the businessman. Harper; 1953.

4. Porter ME, Kramer MR. The competitive advantage of corporate philanthropy. Harvard Business Review. 2002; 80(12):56-68.

5. Fifka MS. Towards a more business-oriented definition of 
CSR: discussing the core controversies of a well-established concept. Journal of Service Science and Management. 2009; 2(4):312.

6. Russo A, Perrini F. Investigating stakeholder theory and social capital: CSR in large firms and Small and Medium-Sized Businesses (SMEs). Journal of Business Ethics. 2010; 91(2):207-21.

7. Bhattacharya J. CSR: ethical and strategic choice. Asian Books Private Limited; 2012.

8. Sarkar J, Sarkar S. Bridging the welfare gap? CSR in India is Mahendra Dev S, editor. Government Development Report, India, Oxford University; 2015.

9. Companies Act 2013; Bare Act, Section 135 [Internet]. 2016 [cited 2016 Nov 18]. Available from: https://www.mca.gov. in/SearchableActs/Section135.htm

10. Companies Act 2013; Bare Act, Schedule VII [Internet].
2016 [cited 2016 Nov 19]. Available from: www.mca.gov.in/ Ministry/pdf/General_Circular_21_2014.

11. Mahanta V. Good growth in corporate dossier, Economic Times, India; 2014 Nov 28. p. 3.

12. Arora R. Ministry cuts estimate of Cos' CSR spend by half. Economic Times, India; 2014 Sep 30.

13. Tare S. CSR caux initiatives of business. European Society for Periodical Research (ESPRit). 2014; 1(4).

14. Venkatesan R. Making CSR really matter. Economic Times; 2014 Mar 31.

15. Mukherjee J. CSR- The new currency of reputation capital in India, Linked in; 2015 Jun 7.

16. Joshi R. The 2 per cent nettle. Business India. 2016 Jul; $4(7): 25$.

17. Kumar K. Businessmen vow to back Maharashtra CSR project. Economic Times; 2016 Aug 26. p. 6. 